\title{
The passionate oxymoron in Romeo and Juliet
}

\section{René Girard}

\section{OpenEdition \\ Journals}

\section{Electronic version}

URL: http://journals.openedition.org/shakespeare/1035

DOI: 10.4000/shakespeare.1035

ISSN: 2271-6424

\section{Publisher}

Société Française Shakespeare

\section{Printed version}

Date of publication: 1 November 2007

Number of pages: 41-56

ISBN: 2-9521475-4-X

\section{Electronic reference}

René Girard, «The passionate oxymoron in Romeo and Juliet », Actes des congrès de la Société française Shakespeare [Online], 25 | 2007, Online since 10 February 2008, connection on 23 April 2019. URL :

http://journals.openedition.org/shakespeare/1035; DOI : 10.4000/shakespeare.1035 


\section{Shakespeare et l'excès}

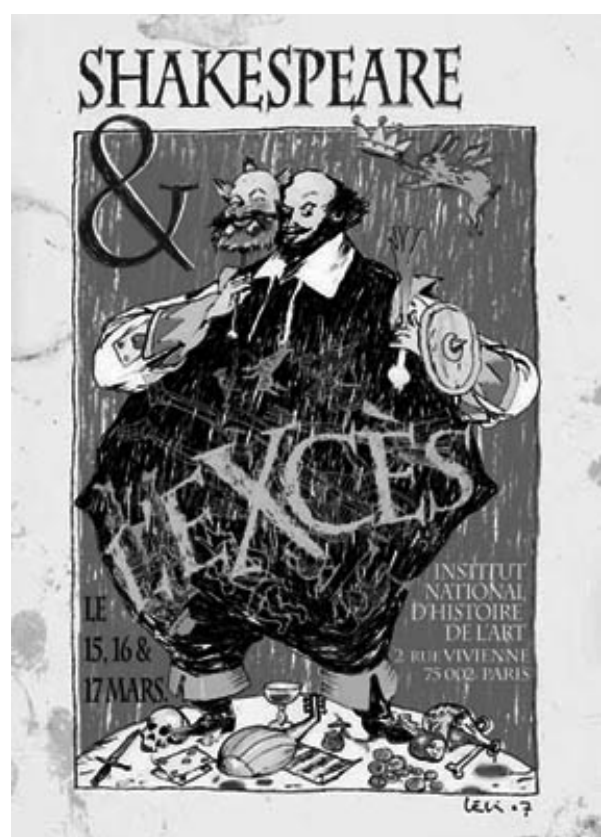

actes du Congrès

organisé par la

SOCIÉTÉ FRANÇAISE SHAKESPEARE

les 15,16 et 17 mars 2007

textes réunis par

Pierre KAPITANIAK

sous la direction de

Jean-Michel DÉPRATS 
COUVERTURE :

Edouard Lekston, Falstaff, 2007

conception graphique et logo

Pierre Kapitaniak

\section{(C) 2007 Société Française Shakespeare \\ Institut du Monde Anglophone}

Université de Paris III - Sorbonne Nouvelle

5 rue de l'École de Médecine 75006 Paris

www.societefrancaiseshakespeare.org

Tous droits de traduction, de reproduction et d'adaptation réservés pour tous les pays 
THE PASSIONATE OXYMORON IN ROMEO AND JULIET

René GIRARD

$\mathrm{I}$

$\mathrm{n}$ the comedies of Shakespeare, all characters infatuated with one another see themselves as perfect embodiments of 'true love.' Love is true to the extent that the two partners in it are interested in each other exclusively and indifferent to intermediaries, gobetweens and third parties in general. 'True love' is the Elizabethan equivalent of what we call a great passion, an authentic passion, l'amour-toujours. It insists on its independence from the entire world, from other people in general. This concept is suffused with the spirit of modern individualism.

If this 'true love' were as independent as it claims, the two lovers would be satisfied with each other's company and never become entangled with anyone else. In the comedies of Shakespeare, the opposite happens. True love constantly runs into trouble. This is what Lysander explains to his beloved Hermia at the beginning of A Midsummer Night's Dream:

Ay me! for aught that ever I could read,

Could ever hear by tale or history,

The course of true love never did run smooth,

The lovers do not feel responsible for the misfortunes of true love. They see themselves as innocent victims of tyrannical parents, jealous friends and other unwanted meddlers. A Midsummer Night's Dream is at one level the celebration of that myth and, at a deeper level, its humorous deconstruction. That is why four lovers are needed instead of two. Their unseemly entanglements during the long and hot midsummer night are blamed on the most charming and preposterous excuse imaginable. Under the pretense of helping the lovers solve their various problems, some mischievous fairies have been squeezing a potent love potion into the eyes of the wrong lovers... 
Behind the self-deceit of 'true love,' the truth is mimetic desire. Far from being rooted deep in the lovers themselves, their adolescent infatuations result from their perpetual imitations of one another and of the books they read. These four lovers predictably end up fighting over the same object, the two boys over the same girl, the two girls over the same boy. These spoiled adolescents have too much time on their hands and too little to worry about. The more they exalt true love in theory, the less they abide by it in practice. This fairy tale is the ballet of mimetic disharmony, so harmonious in its symmetries that this miraculous masterpiece is most often mistaken for a triumph of pure form over content, not quite worthy of its creator's genius.

In a book that I wrote on Shakespeare, ${ }^{1}$ I suggested that authentic 'true love' is nowhere to be found in the early Shakespeare. But I say nothing in that book on the play that seems to contradict this conclusion most spectacularly: Romeo and Juliet of course.

One could argue that the love affair is too short in that play to be tested for its durability but that would be piddling. It must be granted also that Romeo and Juliet are fiercely loyal and honest with one another. One obvious indication of Juliet's 'truth' or 'authenticity' is her refusal to 'act coy' with her lover, unless specifically requested by him to do so:

O gentle Romeo,

If thou dost love, pronounce it faithfully;

Or if thou thinkest I am too quickly won,

I'll frown and be perverse, and say thee nay.

In order to see what is at stake here, one must compare Juliet with another Shakespearean heroine more similar to her than generally realized, Cressida. Just like Juliet, Cressida surrenders too quickly and impetuously to her first lover, Troilus. Just like Juliet, she perceives the danger but, just like Juliet once again, she cannot dissemble and she throws all caution to the winds. Just like Juliet, Cressida rashly bets that her first lover is trustworthy, but with entirely different results.

On the morning after Cressida becomes his mistress, Troilus unwittingly reveals to her his cheap masculine vanity, his mediocrity, his selfishness, his arrogance, his cruel indifference. Those who turn Cressida into a symbol of unprovoked feminine infidelity must be just

${ }^{1}$ A Theatre of Envy: William Shakespeare, Oxford, 1991. 
as sexist as Troilus, I am afraid, since they remain blind to the young man's faults which are glaringly obvious. Far from being a victim, Troilus is twice the corruptor of Cressida. On top of his other faults, he is so naively jealous that he, himself, suggests to his quick-witted mistress the only vengeance available to a woman in her situation.

Romeo and Juliet are very different; they are so incapable of treachery that... nothing really tragic, nothing dramatically exciting should disrupt their relationship.

In such plays as Troilus and Cressida, A Midsummer Night's Dream, etc., the relations between the characters are treacherous enough to provide the incidents that will keep the public entertained. Not so in Romeo and Juliet.

However wonderful and admirable this is in real life, in the theater, this lack of dramatic possibilities is an unmitigated disaster unless, of course, the playwright takes underhanded measures to hide the dramatic inadequacy of 'true love.'

Shakespeare did not need André Gide to teach him that 'good sentiments do not add up to good literature.' In Romeo and Juliet, all dramatic effects are imported from outside the love affair. The solution is the Verona bloodfeud. This is the reason why, from the first to the last line, the mutual hatred of the Montagues and the Capulets plays an enormous role in this play. Shakespeare must constantly return to it in order to spice up his inevitably undramatic love affair. He resorts to several tricks to do this: the famous balcony scene exemplifies the simplest and most obvious of these tricks.

In traditional balcony scenes, some of the suspense at least, is generated by the frightened young lady who threatens to shut her window, even call her father for help. In our case, this resource is not available. Juliet has made it clear that Romeo is welcome at any time not only in the balcony but in the bedroom itself. Romeo knows this and we know it too. We also know that everybody knows. Shakespeare has cut himself off from the sources of traditional suspense so efficiently that he must resort to something else and this something else is always the bloodfeud in Romeo and Juliet. The blood feud is represented by Juliet's ferocious kinsmen who are supposed to be hiding in the bushes. Even for a lesser offense than climbing Juliet's balcony, they would gladly massacre a dozen Montagues before breakfast: 


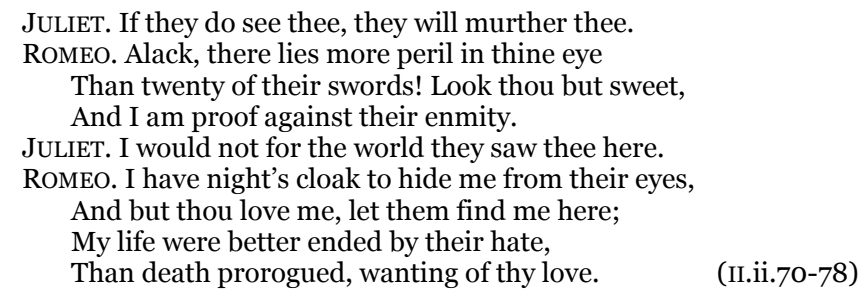

The ferocious relatives never show up. On that particular day, they had the night off obviously, but, until the last second, we feel Romeo and Juliet speak about nothing but them. Even as a subject of conversation, the Capulet kinsmen are sorely needed. Like most young lovers, Romeo and Juliet have just about nothing to say to each other. Romeo keeps pretending that his greatest fear is Juliet's possible indifference to him, more to be feared in his eyes than the entire Capulet military but he is not very convincing. It must be his delicate sense of courtesy that makes him speak in this manner.

It is quite normal for a bloodfeud to spread fear and violence in the vicinity. Nothing surprising there. What is more remarkable, in Romeo and Juliet, is the extent to which the bloodfeud affects the language of passion, especially Juliet's expression of her love for Romeo. The bloodfeud becomes a kind of literary device and that is an amazing role for a bloodfeud to play, which is nothing, after all, but an endless chain of vengeance.

In order to elucidate this aspect, I must first recall a problem much discussed fifty or a hundred years ago, and it was the rather flamboyant rhetoric in Romeo and Juliet. The most noticeable figure of speech is the oxymoron, of course. It consists in juxtaposing two emotional opposites, joy and sadness, pleasure and pain, above all love and hatred.

As we all know, in the love poetry of early modern Europe there is a strong impulse to associate words of passionate love with words of intense hostility. Early $20^{\text {th }}$ century critics felt uncomfortable with the oxymoron in general and the official reason was the inner contradiction that it implies. Opposites are by definition incompatible and to bring them together in a single figure of speech seemed 
unreasonable. A literary work with too many oxymora was regarded too irrational to reach genuine greatness.

The old humanistic critics regarded oxymora as a sign of selfindulgence on the author's part, a youthful weakness perhaps in the case of Romeo and Juliet. Is the oxymoron fever bad enough in this play to require its exclusion from the list of Shakespeare's 'unquestioned masterpieces?' This debate seems a little naive today but no one then disputed its legitimacy.

One of the reasons why this affair seemed important, in the case of Romeo and Juliet, was the prominence of 'true love' in that play. The critics of that time had a romantic soul, really, always a little at odds with their sense of responsibility they felt as 'serious critics.' They regarded authentic love as the greatest emotion of the human heart. Since there is precious little of it in Shakespeare's theater, even by the most optimistic estimates, Romeo and Juliet assumed a great importance in their eyes. Is it not fitting that the supreme playwright in the English language would have devoted at least one of his 'unquestioned masterpieces' to the exaltation of true love? Romeo and Juliet seemed the best candidate for the role. Hence the eagerness to rank this play with 'the bard's unquestioned masterpieces.' The main obstacle was the excessive abundance of oxymora in that play. Do they not suggest that the author failed to regard it with all the seriousness an unquestioned masterpiece deserves?

The most spectacular collection of oxymora in the whole play is Juliet's reaction to the news that Romeo has killed her first cousin and childhood friend Tybalt:

$$
\begin{aligned}
& \text { O serpent heart hid with a flow'ring face! } \\
& \text { Did ever dragon keep so fair a cave? } \\
& \text { Beautiful tyrant! Fiend angelical! } \\
& \text { Dove-feather'd raven! Wolfish ravening lamb! } \\
& \text { Despised substance of divinest show! } \\
& \text { Just opposite to what thou justly seem'st, } \\
& \text { A damned saint, an honorable villain! } \\
& \text { O nature, what hadst thou to do in hell } \\
& \text { When thou didst bower the spirit of a fiend } \\
& \text { In mortal paradise of such sweet flesh? } \\
& \text { Was ever book containing such vile matter } \\
& \text { So fairly bound? O that deceit should dwell } \\
& \text { In such a gorgeous palace! }
\end{aligned}
$$


When considered in and by themselves, these oxymora make little sense. Take the expression 'fiend angelical' for instance. A 'fiend' and an 'angel' are poles apart and to associate the two seems absurd. If Juliet regards Romeo as a fiend, she should say so and leave it at that. If she regards him as an angel, she should says so and keep quiet. To fuse the two together and call Romeo a 'fiend angelical' is a contradiction in terms and it should be avoided.

Such is the traditional reasoning against oxymora. It fails to take into account the fact that even in the most quiet lives, enormously upsetting events with opposite impacts may occur in such quick succession that they impinge on one another and chaos results. This is precisely what's happening to Juliet. She has fallen in love with a man she should regard as a murderer, now more than ever, since he has killed Tybalt. The old hatred is fighting with her new love in such a way as to turn her heart into a jumble of opposites, endlessly clashing together.

The real question is not the intrinsic reasonableness of oxymora but how appropriate they are to the chaotic situation of the character who resorts to them. As a lover, Juliet blesses Romeo; as Tybalt's cousin, she curses him. Juliet is a living oxymoron therefore.

My explication of the oxymora is commonsensical really since it is demanded by the plot. But the plot, here, is not the whole story; it does not really account for the impression made by Juliet's tirade. The oxymora are simply too numerous, too spectacular, too stereotyped as well - most of them appear elsewhere in other Shakespeare plays - to make us suspect some irony on the author's part, some deliberate parody.

Is Shakespeare really trying to portray Juliet, or rather himself as a compulsive producer of oxymora? He must have had something more interesting in mind, something more relevant to the nature of this particular play. What is there to be ironic about?

It is remarkable that, in the tirade that I quoted, there is not one reference to the violent death of Tybalt or even to Tybalt himself, not one allusion to the supposed cause of this amazing assemblage of rhetorical figures.

If we read this text as a separate poem in an anthology, a reading which, at least underhandedly, Shakespeare seems to invite, what impression will it make on us? If we did not know where this text 
comes from, we would never suspect that it is triggered by the violent death of a close relative. It would sound to us like the speech of a woman whose reasons to grieve come from her lover, no doubt, and are directly rooted in the love affair itself, in his behavior as a lover, not in the death of some relative. We would guess that the speaker has some reason to distrust the man with whom she is madly in love. She seems to fear that, in return for her love, he does not love her half as much as he should. She suspects something dreadful from the standpoint of her passion, more dreadful than the death of a dozen relatives, some infidelity of course...

The worst aspect of the situation, as we would imagine it, is that, far from being diminished by the young man's probable betrayal, the speaker's passion is increased beyond measure and she is humiliated, she is deeply ashamed of herself. She should return the culprit's indifference with an even stonier indifference; she should serve him a dose of his own medicine and make her indifference manifest but she cannot do it. She feels utterly defeated. She cannot forget the angel behind the fiend that her lover has become for her: he really fits the 'fiend angelical' formula.

Before learning about Tybalt's death, Juliet might have compared Romeo to an 'angel,' but not to 'a fiend.' In the oxymoron 'fiend angelical,' the angel is still with us but it is associated to the repulsive 'fiend.' The language of 'true love', in principle, should be entirely positive; it should be composed only of words of affection, praise, admiration, tenderness... The oxymora associate these words with others that mean the very opposite, words that suggest dislike, blame, abhorrence, fear, even hatred..., here the word 'fiend.'

This type of combination, it seems, should result in an overall weakening of the passion that Juliet feels for Romeo. When hatred is added to some already existing love, the result should be a subtraction, a diminution, a weakening of the previous erotic tension, rather than an increase. A mixture of hot and cold should produce a lukewarm desire.

The oxymoron does not work that way at all. Instead of lowering the temperature of the passion, it makes it go up. The mixture of love and hatred suggests a love much stronger than the one unmixed with hatred, the one conveyed by a mere accumulation of loving and positive words. 
This is not how all the hysterical oxymora operate not only in Shakespeare but in all love poems of the Renaissance baroque era. The favorite topic is the exasperated despair of a spurned lover. The oxymoron is the language of erotic jealousy, not the language of mourning. Shakespeare is aware, I feel, of the real impression conveyed by Juliet's tirade and, far from emphasizing the secret décalage with the plot, he seems eager to reinforce the feeling the delicate reader must have that something is slightly out of kilter.

The great tirade conveys the impression of a woman madly in love, literally obsessed with Romeo. Juliet has no objective reason to be jealous but Shakespeare is too skillful a writer not to know that the stronger desire lies with the frustrated rather than the happily fulfilled love affair.

This the paradox of the oxymoron: in the right context, a 'fiend angelical' will sound more desirable than a mere angel. Why should that be? The negative feelings that, logically should extinguish passion, jealousy, anger, resentment, in reality make it seem stronger. Even though the love of Romeo and Juliet has been defined as innocent and sweet, it obviously obeys that law. Without the oxymora, Juliet's love for Romeo would sound less hysterical, less intense, therefore, than is desirable. How is this possible?

In order to explain this magic, one must situate the oxymoron in the context of mimetic desire, the type of desire I briefly mentioned in my opening sentences, à propos of $A$ Midsummer Night's Dream. Whenever we desire mimetically, I said, we imitate the desire of someone we admire and we turn it into our own, with the almost inevitable result that we desire the same object as our model, the same woman for instance, like the two boys in A Midsummer Night's Dream. They both love Hermia at the beginning of the play and then, later into the night, they both love Helena. They both shift from one girl to the other and, since they always shift at the same time, under each other's influence, the rivalry cannot be purely coincidental. The mimetic agreement of two lovers is really the worst possible disagreement. The same is true of the two girls. The one invariant in the whole system is universal rivalry which can only breed universal frustration...

The law of mimetic desire is universal frustration. If you believe that this law is defeated each time one of the rivals decisively triumphs over the other, you are mistaken. The victor appropriates the disputed 
object but his resulting happiness does not last. A safely possessed object is an object that no powerful model and rival designates to us and it quickly looses its mimetic allure. The only objects that remain permanently desirable are inaccessible objects, the ones designated by models too powerful to be vanquished.

In a world full of hypermimetic individuals, such as the Elizabethan court, or our own consumer society, the principle of frustration is inexorable. The honest reason why the course of true love never did, never does and never will run smooth is that this so-called true love is really not true at all; it is a mimetic desire unable and unwilling to acknowledge its own mimetic nature, a desire that becomes really intense and durable only when it is frustrated by a victorious model and rival.

All mimetic addicts, both males or females, are really addicted to indifference and rejection. This is no masochism in the pompous sense of psychoanalysis, no 'love of suffering.' It is the way things are. It is the mimetic mechanism that creates its own nemesis by always preferring the mediated to the unmediated, the inaccessible, therefore, to the accessible.

Mimetic addicts cannot permanently desire someone who responds positively to their own desire and they cannot remain permanently indifferent to someone who is really indifferent to them. The inaccessible woman often combines the roles of object and model, or mediator. She knows how to keep her lover at bay in order to insure his continued enslavement to her. This is how the 'dark lady' in the Sonnets acts with the poet. She plays the mimetic game with consummate skill and makes the poet jealous. She knows how to exploit the laws of mimetic desire to her own advantage.

All possible combinations of mimetic desire always obey the law just defined: there is an inverse relationship between the intensity of a desire and its prospects of fulfillment. Mimetic desire is the infallible recipe for a life of endless frustration, perfectly exemplified by Duke Orsino in Twelfth Night. Since intense love is always unrewarded, it always coincides with an intense resentment of the beloved.

It is this combination of passion and resentment that the oxymoron perfectly expresses. There is no love that does not entail some hatred and, reciprocally, no hatred that cannot mysteriously convert to intense passion, if only for an instant, as in the case of 
Aufidius and Coriolanus. Far from being an 'artificial' figure of speech, therefore, as bourgeois optimism suggests, the oxymoron perfectly expresses the type of mimetic relations that love affairs become when they are constantly blocked by mimetic rivalry, real or imagined.

The widespread use and abuse of the oxymoron in the still aristocratic world of early modern literature is not quite the artificial fashion that 'serious critics' claim it is. It is rooted in the way erotic relations really were in that world, subject to the same type of frustrations and dysfunctionalities that dominate our own cultural world today, in an even more conspicuous and brutal manner.

In such a world, the educated public becomes accustomed to associate the stronger passion with the figure of speech that brings opposites together, love and hatred, sentiment and resentment, sympathy and antipathy. It corresponds to the endless impasse of courtly life, or salon life.

Thanks to the bloodfeud, Shakespeare can bring back into Romeo and Juliet these conjunctions of opposites that should not be there in the case of these two lovers, since their relationship is supposed to be perfect. Shakespeare knows that his public is unable to conceive passionate desire except in terms of oxymora, in other words in terms of extreme frustration. Thanks to the murder of Tybalt, thanks to the bloodfeud, Shakespeare can bring the oxymoron back into the picture under false pretenses, surreptitiously in other words. The death of Tybalt in a duel is not a criminal offense, since Romeo did everything he could to avoid it. It is a mere pretext, really, for the avalanche of oxymora that follows.

If Shakespeare had played the game of true love with complete honesty, he would have renounced the oxymoron altogether, at the risk of disappointing his contemporary audiences. The love of Romeo and Juliet should be free by definition from all violence since it is supposed to be authentically 'true.' In order to make it seem intense enough, Shakespeare had to buttress it with imagery more appropriate really to the various dirty tricks and infidelities that mimetic lovers play on one another, than to Romeo and Juliet. To make this violence seem legitimate, instead of rooting it where it really belongs, in the erotic relations themselves, Shakespeare systematically projected it onto the bloodfeud. 
True love is supposed to be the most intense desire but, in reality, it is too perfect and peaceful a relationship to really satisfy a theater audience. It lacks the spice that only a little violence between the lovers can bring to their relationship. Shakespeare needs the mimetic disturbances that the oxymora suggest but he cannot give Juliet the usual reasons lovers have to be angry at each other without tarnishing their perfect image of true love, without destroying the myth he has decided to give us. In order to keep his 'true love' both sufficiently true and sufficiently intense, the only way is to resort to the bloodfeud underhandedly and this is what he did, systematically.

Thanks to the murder of Tybalt, Juliet can be furious at Romeo and sound insanely jealous without having any real cause of jealousy. Shakespeare does everything he has to do under the mask of the bloodfeud. He has Juliet unleash a veritable storm of oxymora without making her sound like the dark lady in the Sonnets.

The true love of Romeo and Juliet should exclude all the cruel mimetic tricks lovers play on one another but, if Shakespeare followed that rule to the letter, the result would be a sentimentally correct but insipid drama. In order to conjure up the feeling of intense passion that his public expects, without paying the price that this choice entails, he must resort to some contraband violence and this is precisely what the bloodfeud is there to provide.

Tybalt's death really replaces the infidelity that Romeo should commit in order to justify the sentiments implied in Juliet's oxymora. Thanks to the bloodfeud, Shakespeare can give the impression of intense jealousy without any unwanted consequences for the purity of the true love between Romeo and Juliet.

Juliet's old nurse is the only other character on stage during Juliet's great tirade, her only audience therefore. She is a very simple woman and a loyal member of the great Capulet clan. Quite understandably, she wishes that Juliet would forget her passion for Romeo. When she hears words of intense hatred for this young man she takes them at face value therefore, and she feels greatly relieved. Juliet seems to be talking like a loyal Capulet once again and the nurse welcomes the 
change. In order to encourage this evolution, she loudly exclaims: 'Shame come to Romeo!'

This simple woman does not understand the peculiar logic of the oxymoron. She applies her commonsense to the great tirade and she misunderstands it. Seeing that words of hatred are added to Juliet's usual praise of Romeo, she automatically assumes that the hatred is replacing the love. She falls into the trap that all people hysterically in love set for those around them. She assumes that Juliet means what she says and says what she means.

When Juliet hears Romeo insulted by the nurse, she flies into a rage:

Blister'd be thy tongue

For such a wish! he was not born to shame;

Upon his brow shame is asham'd to sit;

For 'tis a throne where honor may be crown'd

Sole monarch of the universal earth.

$\mathrm{O}$, what a beast was I to chide at him!

(III.ii.90-95)

Juliet perfectly understands the mistake of the nurse and the proof is that she couches her reply in an unambiguously positive language just to make sure that the nurse, this time, will not misunderstand her. Something a little similar happens between Friar Laurence and Romeo. When the priest begs his pupil to renounce his unintelligible jargon, Romeo immediately explains very clearly why he left Rosaline for Juliet. The first girl did not respond to his advances whereas Juliet does.

Juliet's anger against the nurse is characteristic of poets and artists when an uneducated public misunderstands their finer points. The nurse did not realize that Juliet's great tirade signifies an increase, not a decrease in the temperature of her passion for Romeo.

Thanks to the bloodfeud, Shakespeare can have his cake and eat it too; he can blame the bloodfeud for a violence that, in reality plays a positive role in the language of the two lovers. It is this violence that makes the love of Romeo and Juliet sound like real passion.

Like all great styles with a long history behind them, the oxymoric style of Romeo and Juliet is less artificial than it seems. It is a realistic representation of how lovers relate to each other in a hypermimetic world, more realistic than our contemporary critics are willing to acknowledge. It is this realism of the oxymoron, as a matter 
of fact, that our anti-realistic critics do not see, because they do not see the mimetic nature of our desires and its consequences. The oxymoron may be regarded, I believe, as the literary forerunner of the deluge of violence and pornography that is submerging nowadays the last remnants of our culture.

Thanks to Tybalt's death, Juliet sounds as painfully divided against herself as a passionate lover should be, while still appearing serenely united with Romeo. Far from being a hindrance, the bloodfeud is indispensable to the impression of intense passion conveyed by a relationship that, left to itself, could not generate the conflictual intensity required by the supposedly torrid love affair.

The Tybalt tirade is caricatural not because Shakespeare is unable to achieve a fuller integration of all the elements involved in his literary game but because, in that particular passage, I believe, his purpose is humorously didactic. He wants his more perceptive spectators to detect the game he is playing. This passage has a parodic quality that, inevitably, makes it less successful esthetically. In order to make his intention obvious, Shakespeare goes a little too far with his oxymora. He caricatures his own technique in order to make it comically obvious to the most sophisticated part of his audience. In other passages of the same play, the various elements in the total mixture are so smoothly integrated to one another that, when we hear the play performed, the harmony is such that we are not tempted to isolate and analyze the component parts. The fusion of the words that pertain to the love affair and those that pertain to the bloodfeud is convincing enough for the whole thing to sound like the splendid expression of a love of such depth and intensity that any further question would seem sacrilegious.

One example only..., four simple lines of Juliet once again, at the end of her first encounter with Romeo. She has just learned that the young man with whom, one minute before, she has fallen in love is sole heir to the Montague family. Here is how she reacts to the news:

My only love sprung from my only hate!

Too early seen unknown and known too late!

Prodigious birth of love it is to me

That I must love a loathed enemy.

(I.V.138-141)

It would impossible for Juliet to be more straightforward and factual about the situation than she is here. It is really with a loathed enemy 
that she is in love. Just as in the case of Tybalt's death, she cannot say anything about the situation in which she finds herself without reinventing the oxymoron.

These four lines are based on exactly the same principle as the great tirade I analyzed at length. Each statement looks like an oxymoron, sounds like an oxymoron, functions like an oxymoron and yet it must not be an oxymoron since the whole thing is not metaphoric at all; it is a purely factual statement, rooted in the family background of the heroine's love at first sight. There is no allusion to some kind of internal battle that would rage in Juliet's heart and yet, unquestionably, thanks to the 'quasi-oxymora' provided by the bloodfeud, these four lines sound more passionate than they would, had Shakespeare failed to incorporate the bloodfeud to the love affair.

If the word 'love' in the first line were not balanced with the word 'hate,' it would not sound right. The same is true of the last line. If the word 'love' were not followed first by 'hate' and then by 'loathed enemy,' Juliet would not sound as mysteriously transported as she does. The halo of archaic sacredness that seems to be there is rooted in the violence of the bloodfeud and, if we eliminate the bloodfeud, it disappears.

In spite of all the violence in Juliet's language, her relationship with Romeo always looks as fresh as pure snow. And that is really the purpose of the whole rhetorical leger-de-main. The 'oxymoric style' of Romeo and Juliet is a mutual contamination of the love affair and the bloodfeud that produces some poetic miracles as well as some deliberately ludicrous effects.

Romeo is really Juliet's loathed enemy not as a lover but as a member of the Montague family. And yet we feel that Juliet's love is not only intensified but 'deepened' by the addition of 'hate,' in the same line. The interpenetration of the bloodfeud and the love affair is supposed to occur accidentally but, in reality, it is the doing of the playwright who is completely aware that he must import some violence into his play, in a fashion that, far from ruining the love for us, will seem to increase it.

Our four lines are more successful esthetically than Juliet's great tirade because everything in them is factually as well as poetically justified and their 'rhetorical' dimension is less visible. In the great tirade, Shakespeare makes himself less skillful on purpose, like an 
expert who shows some students or friends how to proceed with some delicate manipulation by making himself deliberately less adroit than he normally is, easier therefore to imitate.

Recently, a French critic, Olivier Maurel has pointed out that the 'star-crossed lovers' are just as mimetic as the characters in the comedies. If Shakespeare really interpreted his own play in the habitual 'romantic' fashion, would he have shown, at the beginning, a Romeo already madly enamored with a Capulet girl but not the right one, a certain Rosaline whom he showers with the poetic clichés he will redirect at Juliet a little later? If Shakespeare intended Romeo and Juliet to be genuine paragons of true love, would he have represented them as little mimetic snobs? This is certainly what he does at the beginning of the play: after Romeo kisses Juliet for the first time, she exclaims: 'you kiss by the book,' not to blame his lack of spontaneity but to applaud his perfect obedience to fashion.

Lady Capulet is so aware of Juliet's snobbish literariness that, to predispose her in favor of the man she and her husband want her to marry, this mother literally woos her daughter and recites to her an extremely contrived little poem about Count Paris, such as Juliet herself might write for Romeo.

Olivier Maurel is right: Romeo and Juliet resemble all classical figures of mimetic desire in Western literature, and Shakespeare artificially immunized their relationship from the disruptive consequences of that desire. He wants Romeo and Juliet to pass the test of 'true love' with flying colors and he sees to it that they do. All the make-believe that goes into the myth of Romeo and Juliet, including the artificiality of the double suicide, Shakespeare will explicitly mock, a little later, in the play within the play of AMidsummer Night's Dream, the story of Pyramus and Thisbe which is, among other things, a hilarious satire of Romeo and Juliet.

If Shakespeare had not manipulated our mimetic desire a little, he could never have turned the story of Romeo and Juliet into the rather formidable romantic myth that it has become. There is something clandestine about the exploitation of violence in this play because Shakespeare insists at the same time that the violence of the bloodfeud is totally alien to Romeo and Juliet who, both in the prologue and in the conclusion, are defined as innocent victims of the bloodfeud and the bloodfeud itself is identified with the old generation. 
In Romeo and Juliet, the hate inside the love plays a role equivalent to that of the pharmakon ritual in the dionysiac cult of ancient Greece. This violence is good and bad at the same time, violent and peaceful more or less simultaneously. It may be observed that Friar Laurence, the man who tries and fails to manipulate everybody and everything in the play, may well be a humorous symbol of the author and director that Shakespeare himself was. The first thing the friar does when he first appears on the stage is to give on the subject of the pharmaceutical pharmakon a fascinating speech that can be read as an allegory of Romeo and Juliet in its entirety. It suggests that Shakespeare was aware of the sacrificial compromises with the truth that the rhetorical technique of this play entailed and he warns his more knowledgeable readers about the ambivalent role of violence in it:

Oh! mickle is the powerful grace that lies

In plants, herbs, stones and their true qualities;

For naught so vile that on the earth doth live

But to the earth some special good doth give,

Nor aught so good that strain'd for that fair use

Revolts from true birth, stumbling on abuse:

Virtue itself turns vice, being misapplied,

And vice sometime's by action dignified.

Within the infant rind of this weak flower

Poison hath residence and medicine power;

For this, being smelt, with that part cheers each part;

Being tasted, slays all senses with the heart.

Two such opposed kings encamp them still

In man as well as herbs, grace and rude will;

And where the worser is predominant,

Full soon the canker death eats up that plant.

(II.iii.15-30)

René GIRARD 